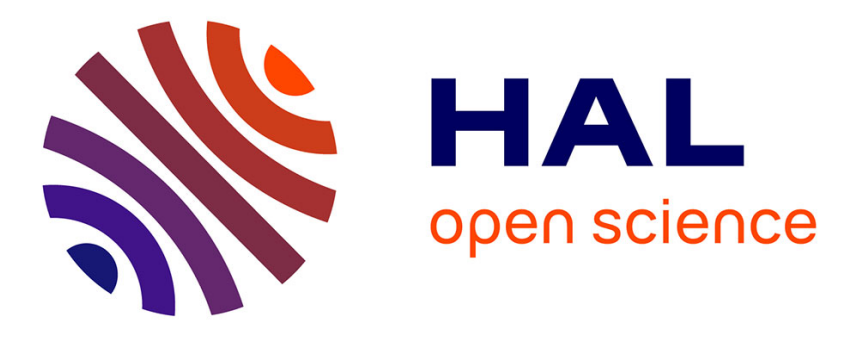

\title{
LPA as a paracrine mediator of adipocyte growth and function.
}

Céline Pagès, Alexia Girard, Olivier Jeanneton, Pierre Barbe, Claude Wolf, Max Lafontan, Philippe Valet, Jean Sébastien Saulnier-Blache

\section{- To cite this version:}

Céline Pagès, Alexia Girard, Olivier Jeanneton, Pierre Barbe, Claude Wolf, et al.. LPA as a paracrine mediator of adipocyte growth and function.. Annals of the New York Academy of Sciences, 2000, 905, pp.159-64. inserm-00110167

\section{HAL Id: inserm-00110167 https://www.hal.inserm.fr/inserm-00110167}

Submitted on 8 Jan 2007

HAL is a multi-disciplinary open access archive for the deposit and dissemination of scientific research documents, whether they are published or not. The documents may come from teaching and research institutions in France or abroad, or from public or private research centers.
L'archive ouverte pluridisciplinaire HAL, est destinée au dépôt et à la diffusion de documents scientifiques de niveau recherche, publiés ou non, émanant des établissements d'enseignement et de recherche français ou étrangers, des laboratoires publics ou privés. 


\title{
LPA as a Paracrine Mediator of Adipocyte Growth and Function
}

Céline Pagèsa, Alexia Girarda, Olivier Jeannetona, Pierre Barbea, Claude Wolf $b$, Max Lafontan $^{a}$, Philippe Valet ${ }^{\mathrm{a}}$ and Jean Sébastien Saulnier-Blachea,\#. a I.N.S.E.R.M U317, Institut Louis Bugnard, Université Paul Sabatier, CHU Rangueil, Batiment L3, 31403, Toulouse cedex 04, France. b C.N.R.S. URA 1283, CHU St Antoine, Paris France. \# corresponding author: saulnier@rangueil.inserm.fr. Contract grant: Institut National de la Santé et de la Recherche Médicale, APEX \#4X405D

\begin{abstract}
Adipogenesis corresponds to the recrutment of new adipocytes in adipose tissue and results from proliferation/differentiation of preadipocytes. Production of paracrine and autocrine factors by adipocytes play an important role in adipogenesis. We recently demonstrated the existence of an adipocyte production of lysophosphatidic acid (LPA) both in vitro and in situ. This production is modulated by catecholamines via $\alpha 2$-adrenergic receptors. Adipocyte-LPA present in conditionned media increases the growth of a preadipose cell line in culture. This is associated with an activation of Mitogen Activated Protein Kinases, and of the Focal Adhesion Kinase. Because of the close proximity of preadipocytes and adipocytes within adipose tissue, adipocyte-LPA could play an important role in autocrine/paracrine control of adipogenesis.
\end{abstract}

\section{Introduction}

In obesity, adipose tissue overgrowth is associated with adipocyte hypertrophy and adipocyte hyperplasia. Hypertrophy results from excessive triglyceride accumulation in adipocytes. Hyperplasia results from recrutement of new adipocytes involving proliferation and differentiation of preadipocytes: adipogenesis. Identifying factors regulating adipogenesis, is a major point in understanding normal and pathologic growth of adipose tissue. Many hormones, growth factors and cytokines, such as insulin, catecholamines, IGF-I, growth hormone, glucocorticoids and thyroid hormone, are known to promote proliferation and/or differentiation of preadipocytes (1-3). Production of paracrine and autocrine factors by adipocytes themselves could also play an important role. Adipocytes produce several peptidic (TNF $\alpha$, adipsin, angiotensinogen or leptin) and lipidic factors (fatty acids, prostaglandins, monobutyrin) all involved directly or not in adipogenesis $(2,4-6)$.

Among the different factors controling adipose tissue growth, catecholamines (epinephrine and norepinephrine) play an important role. These mediators act through different receptor subtypes: $\beta 1, \beta 2, \beta 3, \alpha 1$ and $\alpha 2$ coupled to several intracellular transduction pathways (7). Our group is interested in understanding the contribution of the different 
adrenergic receptors in the control of adipogenesis. We previously demonstrated the involvement of catecholamines in the control of preadipocyte proliferation, a key event in adipogenesis. This trophic activity involves the specific activation of $\alpha 2$-adrenergic receptors and the activation of Mitogen Activated Protein Kinases, Focal Adhesion Kinase and the small GTPase p21rhoA (8-10). Recent studies suggest that in addition to those intracellular transduction pathways, an autocrine/paracrine loop involving lysophosphatidic acid (LPA) could also play an important role in $\alpha 2$-adrenergic control of adipogenesis (11).

\section{Adipocyte production of lysophosphatidic acid}

Experiments which allowed to propose the existence of an $\alpha 2$-adrenergic-dependent production of LPA by adipocytes were based on utilization of conditionned media (CM). Adipocytes were isolated from human adipose tissue or obtained in culture after differentiation of the murine adipose cell line $\alpha 2 \mathrm{AF} 2$ (8). Both type of adipocyte express abundant functional $\alpha 2$-adrenergic receptors. CM were prepared from adipocytes exposed or not to $\alpha 2$-adrenergic agonists, and tested for their ability to exert trophic activities on $\alpha 2$-adrenergic insensitive preadipocytes (3T3F442A cell line). Control CM (CCM) induced a rapid (within minutes) reorganization of preadipocyte actin cytoskeleton (cell spreading) followed (after $48 \mathrm{~h}$ ) by an increased in preadipocyte number. Those effects were significantly increased with CM prepared from $\alpha 2$-adrenergic-stimulated adipocytes $(\alpha 2 \mathrm{CM})$. This additional effect was completely suppressed by pretreatment of $\alpha 2 \mathrm{CM}$ with a lysophospholipase (phospholipase B: PLB). This suggests the existence of an $\alpha 2$-adrenergic-dependent production of a trophic lysophospholipid by adipocytes. Among different lysophospholipids tested, only 1-oleoyl-LPA and sphingosine-1-phosphate (S1P) were able to reproduce the effects of $\alpha 2 \mathrm{CM}$. S1P being insensitive to phospholipase $\mathrm{B}$, we proposed that LPA was responsible for the trophic activities of $\alpha 2 \mathrm{CM}$. This was supported by presence of [32P]LPA in $\alpha 2 \mathrm{CM}$ prepared from [32P]Pi prelabelled adipocytes. In order to estimate the amount of LPA produced by adipocytes, phospholipids present in $\alpha 2 \mathrm{CM}$ were chemically derivatized with a fluorescent molecule (1pyrenyl diazomethane), separated by thin layer chromatography, and fluorescence was quantified. Concentration of LPA in $\alpha 2 C M$ was estimated to $280-360 \mathrm{nM}\left(0.7-0.9 \mathrm{nmol} / 10^{6}\right.$ cells). This amount of LPA is close to that produced by platelets (12) and ovarian cancer cells (13).

LPA is relatively abundant in plasma (bound to albumin) produced by agregating platelets $(12,14)$. It is also found in other biological fluids such ascites (15), cerebro spinal liquid (16), aqueous humor (17). Eventhough LPA can originate from various metabolic pathways (12), several groups have proposed that its production mainly results from phospholipase A2 (PLA2--catalysed deacylation of phosphatidic acid (13, 19, 20). In order to determine the existence of adipocyte production of LPA in situ, a microdialysis probe was implanted in human subcutaneous adipose tissue and perfused with or without an $\alpha 2$ - 
adrenergic agonist. The presence of LPA in microdialysates was tested using a bioassay. Microdialysates obtained in the presence of the $\alpha 2$-adrenergic agonist exibited stronger LPAlike activity as compared to control microdialysates. This revealed the presence of LPA in extracellular fluid of human adipose tissue.

\section{LPA effects on preadipocyte growth}

LPA is known as a potent bioactive phospholipid able to regulate a number of cellular events including proliferation and differentiation. Most of the cellular responses generated by LPA involve specific G-protein coupled cell surface receptors. Four G-protein coupled receptors can potentially transduce LPA signals in mammals: vzg1/edg2, edg4, PSP24 and edg1 (21-25). Those receptors can be coupled to Gi/Go heterotrimeric proteins, leading to activation of the mitogen activated protein kinases (MAPK) or inhibition of adenylyl cyclase. LPA receptors can also be coupled to G12 or G13 heterotrimeric proteins leading to activation of the Focal Adhesion Kinase (FAK) and actin cytoskeleton reorganization via the small GTPase p21rhoA (18). In preadipocytes, 1-oleoyl-LPA (the most active form of LPA) generated both short term and long term effects. Twenty minutes treatment of serum deprived 3T3F442A preadipocytes led to a dose dependent (EC50 of 1-5 nM) reorganization of actin cytoskeleton resulting in cell spreading. Similar response was obtained with an other bioactive phospholipid, sphingosine-1-P (S1P). If 1-oleoyl-LPA treatment was maintained for $48 \mathrm{~h}$ it led to a dose-dependent increase in cell number (EC50 of 100-110 nM). It is noticeable that those EC50s are compatible with estimated LPA concentration (280-360 nM, see above) in adipocyte conditionned media. Chronic exposition (twice a day for $48 \mathrm{~h}$ ) of 3T3F442A preadipocytes to 10 $\mu \mathrm{M}$ 1-oleoyl-LPA, strongly desensitized the spreading effect of 1-oleoyl-LPA (12 -fold increase in EC50 and 36\% reduction of the maximal effect). This desensitization was specific to 1-oleoylLPA since in the same conditions S1P spreading effect was not altered. We further analysed the effects of 1-oleoyl-LPA on the activity of intracellular kinases involved in both cell cytoskeleton and cell proliferation. 1-oleoyl-LPA led to a rapid and dose-dependent activation of Mitogen Activated Protein Kinases ERK1 and ERK2, as well as of the Focal Adhesion Kinase p125FAK (Figure 2). Pertussis toxin pretreatment blocked 1-oleoyl-LPA activation of ERK 1 and ERK2, not that of p125FAK. Conversely, the p21rhoA-inhibitor C3-exoenzyme blocked the activation of p125FAK, not that of ERK1 and ERK2. Similarly, 1-oleoyl-LPA-induced preadipocyte spreading was completely blocked by treatment with C3-exoenzyme, not by pertussis toxin. Therefore trophic activity of LPA in preadipocytes involves the activation of two independent but complementary pathways: the ras/MAPK pathway via heterotrimeric G proteins of Gi/Go subtype, and the p21rhoA/FAK/cytoskeleton pathway via pertussis toxin insensitive G proteins likely belonging to G12/G13 subtypes. This strongly support the involvement of Gprotein coupled receptors in trophic activity of LPA in preadipocytes. 


\section{Conclusion}

Our data demonstrate that LPA is produced by adipocytes under $\alpha 2$-adrenergic stimulation, and exerts trophic activities in preadipocytes. Because of the close coexistence of adipocytes and preadipocytes in intact adipose tissue, adipocyte-LPA could play an important role in paracrine/autocrine control of adipogenesis by catecholamines (Figure 3). We are currently trying to depict the precise mecanisms involved in adipocyte production of LPA (involvement of different phospholipase A2 subtypes) as well as in the trophic activity of LPA in preadipocytes (characterization and specific contribution of Edg-receptor subtypes). Adipose tissue is present in a lot of different anatomical locations in the body in close contact with several other tissues (muscle, heart, mamary glands, colon, ...). Because of the pleiotropic trophic activity of LPA, adipocyte-LPA could also play an important role in normal and/or pathologic growth of other tissues. 


\section{References}

1. Ailhaud, G., P. Grimaldi and R. Négrel. 1992. A molecular view of adipose tissue. Int. J. Obesity 16 (Suppl. 2): S17-S21.

2. Spiegelman, B. and J. Flier. 1996. Adipogenesis and Obesity: rounding out the big picture. Cell 87: 377-389.

3. Hauner, H., G. Entenmann, W. Wabitsch, D. Gaillard, G. Ailhaud, R. Negrel and E. Pfeiffer. 1989. Promoting effect of glucocorticoids on the differentiation of human adipocyte precursor cells cultured in a chemically defined medium. J. Clin. Invest. 84: 1663-1670.

4. Amri, E.-Z., B. Bertrand, G. Ailhaud and P. Grimaldi. 1991. Regulation of adipose cell differentiation. I. Fatty acids are inducers of the aP2 gene expression. J. Lipid Res. 32: 1449-1456.

5. Aubert, J., G. Ailhaud and R. Negrel. 1996. Evidence for a novel regulatory pathway activated by (carba)prostacyclin in preadipose and adipose cells. FEBS Lett. 397: 117-121.

6. Mohamed-Ali, V., J. Pinkney and S. Coppack. 1998. Adipose tissue as an endocrine and paracrine organ. Int J Obesity 22: 1145-1158.

7. Lafontan, M. and M. Berlan. 1995. Fat cell $\alpha 2$-adrenoceptors: the regulation of fat cell function and lipolysis. Endocrine Rev. 16: 716-738.

8. Bouloumié, A., V. Planat, J.-C. Devedjian, P. Valet, J.-S. Saulnier-Blache, M. Record and M. Lafontan. 1994. $\alpha 2$-adrenergic stimulation promotes preadipocyte proliferation. Involvement of mitogen-activated protein kinases. J. Biol. Chem. 269: 30254-30259.

9. Bétuing, S., D. Daviaud, P. Valet, A. Bouloumié, M. Lafontan and J. Saulnier-Blache. 1996. $\alpha 2$-adrenoceptor stimulation promotes actine polymerization and focal adhesion in 3T3F442A and BFC-1ß preadipocytes. Endocrinol. 137: 5220-5229.

10. Bétuing, S., D. Daviaud, C. Pagès, E. Bonnard, P. Valet, M. Lafontan and J. SaulnierBlache. 1998. G $\beta \gamma$-independent coupling of $\alpha 2$-adrenergic receptor to p21rhoA in preadipocytes. (soumis à publication)

11. Valet, P., C. Pagès, O. Jeanneton, D. Daviaud, P. Barbe, M. Record, J. Saulnier-Blache and M. Lafontan. 1998. Alpha2-adrenergic receptor-mediated release of lysophosphatidic acid by adipocytes. J. Clin. Invest. 101: 1431-1438.

12. Gaits, F., O. Fourcade, L. B. F, G. Gueguen, B. Gaigé, A. Gassama-Diagne, J. Fauvel, J.P. Salles, G. Mauco, M.-F. Simon and H. Chap. 1997. Lysophosphatidic acid as a phospholipid mediator: pathways of synthesis. FEBS Lett. 410: 54-58.

13. Shen, Z., J. Belinson, R. Morton and X. Yan. 1998. Phorbol 12-myristate 13-acetate stimulates lysophosphatidic acid secretion from ovarian and cervical cancer cells but not from breast or leukemia cells. Gynecol Oncol 71: 364-368.

14. Moolenaar, W. H., O. Kranenburg, F. R. Postma and G. C. Zondag. 1997. Lysophosphatidic acid : G-protein signalling and cellular responses. Current Opinion in Cell Biology 9: 168-173. 
15. Xu, Y., D. Gaudette, J. Boynton, A. Frankel, X. Fang, A. Sharma, J. Hurteau, G. Casey, A. Goodbody, A. Mellors, B. Holub and G. Mills. 1995. Characterization of an ovarian cancer activating factor in ascites from ovarian cancer patients. Clin. Cancer Res. 1: 1223-1232.

16. Tigyi, G., L. Hong, M. Yakubu, H. Parfenova, M. Shibata and C. Leffler. 1995. Lysophosphatidic acid alters cerebrovascular reactivity in piglets. Am J Physiol 268: H2048-55.

17. Liliom, K., Z. Guan, J.-L. Tseng, D. M. Desiderio, G. Tigyi and M. A. Watsky. 1998. Growth factor-like phospholipids generated after corneal injury. Am. J. Physiol. 274: C1065C1074.

18. Goetzl, E. and S. An. 1998. Diversity of cellular receptors and functions for the lysophospholipid growth factors lysophosphatidic acid and sphingosin 1-phosphate. FASEB J. 12: 1589-1598.

19. Fourcade, O., M. F. Simon, C. Viodé, N. Rugani, F. Leballe, A. Ragab, B. Fournié, L. Sarda and H. Chap. 1995. Secretory phospholipase A2 generates the novel lipid mediator lysophosphatidic acid in membrane microvesicles shed from activated cells. Cell 80: 919-927.

20. Balsinde, J., I. Bianco, E. Ackermann, K. Conde-Frieboes and E. Dennis. 1995. Inhibition of calcium-independent phospholipase A2 prevents arachidonic acid incorporation and phospholipid remodeling in P388D1 macrophages. Proc. Natl. Acad. Sci. USA 92: 8527-8531.

21. Hecht, J., J. Weiner, S. Post and J. Chun. 1996. Ventricular zone gene-1 (vzg-1) encodes a lysophosphatidic acid receptor expressed in neurogenic regions of the developing cerebral cortex. J. Cell Biol. 135: 1071-1083.

22. An, S., A. Dickens, T. Bleu, O. Hallmark and E. Goetzl. 1997. Molecular cloning of the human Edg2 protein and its identification as a functional cellular receptor for lysophosphatidic acid. Biochem. Biophys. Res. Com. 231: 619-622.

23. Guo, Z., K. Liliom, D. J. Fischer, I. C. Bathurst, L. D. Tomei, M. C. Kiefer and G. Tigyi. 1996. Molecular cloning of a high-affinity receptor for the growth factor-like lipid mediator lysophosphatidic acid from xenopus oocytes. Proc Natl Acad Sci USA 93: 14367-14372.

24. An, S., T. Bleu, O. Hallmark and E. Goetzl. 1998. Characterization of a novel subtype of human G protein-coupled receptor for lysophosphatidic acid. J. Biol. Chem. 273: 7906-7910.

25. Lee, M.-J., S. Thangada, C. Liu, B. Thompson and T. Hla. 1998. Lysophosphatidic acid stimulates the G-protein-coupled receptor EDG-1 as a low affinity agonist. J. Biol. Chem. 273: 22105-22112. 


\section{Legends of the figures}

Figure 1: Influence of human adipocyte conditioned media on 3T3F442A preadipocyte spreading. Conditioned media (CM) were prepared from isolated human adipocytes incubated for $16 \mathrm{~h}$ at $37^{\circ} \mathrm{C}$ in Krebs-Ringer albumin buffer supplemented or not (CCM) with $1 \mu \mathrm{M}$ of the selective $\alpha 2$-adrenergic agonist UK14304 (UK) alone $(\alpha 2 \mathrm{CM})$ or in the presence $(\alpha 2 \mathrm{CM}+\mathrm{RX})$ of $10 \mu \mathrm{M}$ of the selective $\alpha 2$-adrenergic antagonist RX821002 (RX). Spreading activity was measured by determining the proportion of refringent cells after 20 min exposure of retracted 3T3F442A preadipocytes to conditioned medium pretreated (+) or not (-) with $3 \mathrm{U} / \mathrm{ml}$ phopsholipase B (PLB) for $37^{\circ} \mathrm{C}$.

Figure 2: LPA activation of the Mitogen Activated Protein Kinases (ERK1-ERK2) and of the Focal Adhesion Kinase (FAK) in 3T3F442A preadipocytes. Serum-deprived 3T3F442A preadipocytes were exposed to $1 \mu \mathrm{M}$ 1-oleoyl-LPA for various period of time. Cells proteins were then solubilized, immunoprecipitated with an anti-phosphotyrosine antibody, separated on SDS-PAGE, transfered on nitrocellulose, and blotted with anti-ERK1/ERK2 (A) or anti-FAK (B) antibodies. * corresponds to the biphosphosphorylated (tyrosin and threonin) and active form of ERK1 and ERK2.

Figure 3: Paracrine control of preadipocyte growth by adipocyte LPA. 